\title{
Peranan Pemerintah Dalam Memberantas Buta Aksara Al-Qur'an
}

(Study Analisis di Kabupaten Sumenep)

Siti Aisyah

Sekolah Tinggi Ilmu Tarbiyah Aqidah Usymuni (STITA)

Jamiah.duba@gmail.com

\begin{abstract}
Miracles of the Qur'an as revealed to the Prophet Muhammad, it means that the scriptures contain "fabulosity" in all its aspects. Nevertheless, the significance of the miracle of the Qur'an is not solely for "fabulosity" weakens the human being in all and sundry, but i'jäz al-Qur'än intent is to clarify the truth of the Qur'an and the Prophet (Prophet Muhammad) who brought it.
\end{abstract}

Keywords: Peranan Buta Aksara al-Qur'an, al-Qur'an, Sumenep 


\section{Pendahuluan}

Kita tentunya sangat apresiatif terhadap Peraturan Daerah (PERDA) bebas buta aksra al-Qur'an, di Kabupaten Sumenep yang tiada lain untuk meningkatkan pengetahuan anak didik usia tingkat dasar. Karena dengan berkembangnya zaman yang begitu penuh dengan tantangan serta peradaban yang terus berubah, maka perlunya kemampuan dan penguasaan baca tulis alQur'an sebagai kitab suci umat islam. Walaupun Perda tersebut mendapat banyak pro dan kontra dari sejumlah pihak. Al-Qur'an adalah kitab suci bagi umat Islam yang kekal, berisi wahyu Allah Swt. yang diturunkan melalui Nabi Muhammad Saw, dengan perantaraan malaikat Jibril dan yang membacanya termasuk ibadah. Dalam beberapa ayat, Al-Qur'an memperkenalkan dirinya sebagai al-kitab (buku), al-dzikr (peringatan), hudan (petunjuk), al-syifa' (obat penawar), al-furqan (pembeda antara yang baik dari yang buruk), maw`izhah (nasehat, wejangan, petuah ). Nama-nama dan atau atribut-atribut ini, secara eksplisit memberi indikasi bahwa Al-Qur'an adalah kitab suci yang berdimensi banyak dan berwawasan luas. Di sinilah letak keotentikan, sekaligus keistimewaan al-Qur'an.

Minat untuk membaca terutama membaca Al-Qur'an dikalangan tingkat sekolah Dasar dan Sekolah Menengah Atas semakin merosot dan hamper tidak ada semangat didalam belajar al-qur'an, berkurangnya semanagt ini dikarenakan anak pada usia tersebut masih belum mempunyai cita-cita dan masih dalam pencarian jatidiri, mereka masih kesenangannya bergaul bebas dengan teman sebayanya sehingga anak tersebut perlu ada perhatian khusus terhadap bagaimana bisa mempunyai keinginan belajar membaca al-qur'an. Dengan senang maka mereka lupa akan kewajibannya sebagai pelajar yaitu belajar. Hal ini dampaknya menjadikan anak malas dan lupa akan belajar alqur'an. Mereka pintar mencari alasan apabila disuruh belajar dan membaca AlQur'an.

Kedudukan dan fungsi Al-Qur'an, adalah sebagai pedoman hidup bagi orang yang bertaqwa (هُدَى للِلْمَنَقِينَ), dan sebagai petunjuk atau bimbingan bagi 
umat manusia (هُدَى للِنَّاسِ). Oleh karena itu, jika nilai-nilai yang termaktub di dalam Al-Qur'an mampu di implementasikan dalam kehidupan, niscaya akan terbentuk kehidupan yang religius, damai dan sentosa.

Cara mengimplementasikan Al-Qur'an dalam kehidupan, adalah mengamal-kan segala isinya. Untuk tujuan itu, terlebih awal diperlukan proses pembelajaran terhadap Al-Qur'an. ${ }^{1}$ Mempelajari Al-Qur'an adalah kewajiban, kaitannya dengan ini, maka salah satu usaha yang harus dilakukan dalam mempelajari Al-Qur'an, ia harus dibaca. Sebab, memang makna dasar AlQur'an adalah "bacaan". Allah Swt berfirman bahwa, فَإِذَا قَرَأَنْاهُ فَانَِّعْ قُرْهَ (Apabila Kami telah selesai membacakannya maka ikutilah bacaannya itu). ${ }^{2}$

Implementasi sekaligus aktualisasi nilai-nilai Al-Qur'an dalam kehidupan, tidak akan terwujud dengan sendirinya tanpa ada kesungguhan untuk mengusahakannya. Al-Qur'an tidak akan mampu memberikan manfaat secara konkrit tanpa ada usaha yang sistematis dan terorganisir dari umat Islam sendiri. Keyakinan inilah yang membawa umat Islam senantiasa berusaha untuk memasyarakatkan Al-Qur'an dengan berbagai cara dan upaya yang dilakukan. Cara dan upaya tersebut, antara lain adalah sebagaimana yang telah dilakukan oleh Pemerintah kabupaten Sumenep dengan menerapkan Perda Pebas Buta Aksara Al-qur'an Pada Satuan Pendidikan Dasar.

Penerapan Perda, di samping merupakam kewajiban konstitusional, juga merupakan kewajiban kultural untuk mengembangkan syiar Islam dalam kehidupan masyarakat. Secara konstitusional, Perda tersebut merupakan perwujudan dari tujuan Pendidikan Nasional yang bermaksud untuk mencerdaskan kehidupan bangsa dan mengembangkan manusia Indonesia seutuhnya yaitu manusia yang beriman kepada Tuhan Yang Maha Esa dan berbudi luhur, memiliki pengetahuan dan keterampilan, kesehatan jasmani dan rohani, kepribadian yang mantap dan mandiri serta rasa tanggung jawab kemasyarakatan dan kebangsaan. Hal ini juga relevan dengan tujuan

\footnotetext{
${ }^{1}$ M. Quraish Shihab, Membumikan Al-Qur'an; Fungsi dan Peran Wahyu dalam Kehidupan Masyarakat (Cet. XIX; Bandung: Mizan, 1999)

${ }^{2} \mathrm{Al}$-qur'an Surat. al-Qiyamah (75)
} 
pendidikan Islam di Indonesia sebagai sub sistem pendidikan nasional berdasarkan Undang-undang Nomor 20 tahun 2003 tentang sistem Pendidikan Nasional, yang bercita-cita untuk terwujudnya dan ber-kembangnya potensi peserta didik agar menjadi manusia yan beriman dan betakwa kepada Tuhan Yang Maha Esa, berakhlak mulia, sehat, berilmu, cakap, kreatif, mandiri, dan menjadi warga yang demoktratis serta bertanggung jawab. Cita-cita tersebut, masih sejalan dengan Undang-undang No. 2 tahun 1989 yang bertujuan untuk terwujudnya insan Islami atau muslim paripurna yang mencerminkan ciri-ciri kualitas manusia seutuhnya.

Kemudian secara kultural, menerapkan Perda Bebas buta Aksara Alqur'an Pada Satuan Pendidikan Dasar di kabupaten sumenep tersebut sesungguhnya didorong oleh suatu keinginan yang sangat luhur, yakni bermaksud meningkatkan kemampuan masyarakat dalam hal baca tulis AlQur'an. Sebab, kebiasaan membaca Al-Qur'an akan melahirkan kecintaan terhadap Al-Qur'an. Kecintaan terhadap Al-Qur'an akan melahirkan motivasi untuk meng-aktualisasikan ajaran-ajaran Al-Qur'an dalam berbagai aspek kehidupan masyarakat. Oleh karenanya, kemampuan baca Al-Qur'an bagi setiap murid SD, SLTP, dan SLTA merupakan bagian dari pendidikan Agama Islam yang memiliki arti strategis untuk ikut mencerdaskan kehidupan bangsa, khususnya dalam rangka menanamkan nilai-nilai iman dan taqwa bagi generasi muda dan masyarakat pada umumnya. ${ }^{3}$

Implikasi konkrit dari menerapkan Perda Bebas Buta Aksara Al-qur'an Pada Satuan Pendidikan Dasar di kabupaten sumenep yang telah disebutkan pada bab II pasal 2 Bebas Buta Aksara Al-qur'an Pada Satuan Pendidikan Dasar diselenggarakan dengan maksud untuk memberantas buta aksara al-qur'an pada Satuan Pendidikan Dasar sebagai persyaratan untuk tamat SD/MI atau bentuk yang lain yang sederajat dan diterima pada tingkat SMP/MTs, atau bentuk lain yang sederajat. Implikasi lain dari penerapan Perda tersebut, tentu

\footnotetext{
${ }^{3}$ Rancangan Peraturan Daerah Kabupaten Sumenep Tentang Bebas Buta Aksara Al-qur'an Pada Satuan Pendidikan Dasar
} 
sangat memungkinkan terwujudnya pemberlakuan otonomi daerah di Kabupaten Sumenep di bidang pendidikan. Sebab, salah satu item terpenting adalah pemerintah daerah tingkat II atau kabupaten diserahkan sepenuhnya (secara otoda) dalam mengelolah sistem pendidikan. ${ }^{4}$

Pemerintah kabupaten sumenep dengan peranannya dalam penerapan Perda bebas buta aksara Al-qur'an pada Satuan Pendidikan Dasar di pemerintahan kabupaten Sumenep, tentu saja mendapatkan respon positif di tengah-tengah masyarakat. Sebagian masyarakat merespon penerapan Perda tersebut dengan cara lebih mengintenfsikan pembelajaran baca Al-Qur'an bagi anak-anak mereka dengan melaksanakan pendidikan informal baca Al-Qur'an di lingkungan rumahtangganya. Sebagian lagi, masyarakat merespon penerapan Perda tersebut dengan cara memasukkan anak-anak mereka di lembaga pendidikan non-formal, misalnya TPA, atau dengan cara memasukkan anak-anak mereka di lembaga pendidikan formal di TKA/TPQ. Hal ini dimaksudkan agar anak-anak mereka setelah tamat di SD, atau SLTP telah terbebas dari buta aksara Al-Qur'an. ${ }^{5}$

Di samping bentuk respon positif bagi masyarakat tehadap penerapan Perda Bebas Buta aksara Al-qur'an Pada Satuan Pendidikan Dasar di kabupaten Sumenep yang telah disebutkan, mungkin juga akan ditemukan bentuk resfon negatif dari sebagian masyarakat terhadapnya, terutama bila yang bersangkutan belum berhasil mengupayakan secara maksimal pemberantasan buta aksara bagi anak-anak mereka, dan akibatnya berdampak buruk sebab anak-anak mereka kelak tidak berhak melanjutkan pendidikannya ke jenjang yang lebih tinggi.

"Ada asap, ada api". Jika tidak ada sebab, tidak mungkin terjadi akibat yang berarti. Menurut Slameto dalam "Belajar dan Faktor-faktor yang Mempengaruhinya", secara garis besar faktor penyebab gagal atau berhasil

\footnotetext{
${ }^{4}$ Undang-undang Nomor 22 Tahun 1999 tetang Pemerintahan Daerah, yang diberlakukan mulai tahun 2001

${ }^{5}$ Repubik Indonesia, Undang-Undang Sisdiknas Tahun 2003 (Bandung: Fokus Media, 2003)
} 
dalam mempelajari sesuatu dikelompokkan menjadi faktor internal dan eksternal.

Faktor internal dibatasi hanya factor psikologis, yaitu perhatian dan minat. Jika anak sudah tidak memiliki perhatian untuk belajar Alquran, jangan harap ia akan pandai membacanya. Apabila anak kehilangan minat untuk mempelajari Alquran, karena penyampaiannya kurang menarik atau tujuannya kurang jelas, anak pun tidak akan bertahan lama dalam mempelajarinya.

Adapun faktor ekstern pertama yang mempengaruhi dalam belajar membaca Alquran adalah orang tua. Peran orang tua sangat berpengaruh terhadap keberhasilan anak. pada kenyataannya, orang tua sekarang ini lebih mengusahakan anaknya untuk ikut les olah raga, matematika, atau bahasa Inggris, ketimbang les mengaji. Hal inilah yang menyebabkan anak tidak mengenal Alquran. Padahal, di akhirat sana tidak ada satu pun dalil yang mengatakan manusia akan ditanyai matematika, bahasa Inggris, atau disuruh lomba olah raga renang.

Faktor eksternal berikutnya adalah media hiburan. Dimungkiri atau tidak, kekhusyukan siswa saat ini dalam belajar Alquran sudah terganggu oleh berbagai acara hiburan. Misalnya saja media jejaring sosial dengan berbagai fiturnya yang dibuat sedemikian rupa sehingga tidak membosankan. Stasiun televise pun berlomba-lomba membuat beragam acara menarik untuk membuat pemirsanya betah menonton nya berlama-lama. Belum lagi game online yang memiliki magnet tersendiri. Faktor eksternal terakhir adalah tidak tersedianya wahana pembelajaran Alquran. Di kota-kota besar atau pedesaan yang agamis, wahana pengajian mungkin masih menjamur. Naming, kondisi berbeda akan terjadi di tempat-tempat tertentu yang langka ustadz. Bahkan untuk mencari orang yang azan dan mau menjadi imam salat pun sulit.

Oleh karena itu, perhatian seluruh elemen, mulai dari pemerintah sebagai pemegang otoritas melalui Kemenag atau dinas terkait lainnya, orang tua, dan sekolah tempat mereka bersosialisasi, sangat dibutuhkan. Kesemuanya 
itu bermuara pada munculnya generasi Muslim yang kian dekat dengan Alquran. ${ }^{6}$

Kalau rajin mendengarkan ceramah ramadhan di layar kaca atau khutbah yang disampaikan pada malam-malam ramadhan, kita bisa menyimpulkan bahwa ada beberapa kategori ceramah yang sering diusung : akidah dan akhlaq. Syariah atau fikih terkadang muncul namun yang ringanringan saja. Seputar sholat, puasa, dan zakat. Itupun baru sebatas anjuran, dan belum masuk hingga kedetailannya.

Materi ceramah seperti itu itu masih sama dengan yang dulu-dulu, dan memang tidak ada salahnya karena manusia adalah tempat lupa dan salah, sehingga peringatan kepadanya harus berketerusan. Materi-materi semacam ini banyak diperdengarkan kepada masyarakat awam, baik di desa maupun di perkotaan.

Lain lagi dengan pendengar dari kalangan mahasiswa. Ceramah di kampus-kampus sudah bukan lagi materi yang sederhana, tetapi banyak yang membahas masalah umat, misalnya perekonomian, politik, pemerintahan, peradilan, dll. Sesuai dengan alam berpikir mahasiswa yang kelak akan menjadi pembaharu di tengah masyarakat.

Namun kadang kala terlihat ketimpangan yang muncul karena kurang dikuasainya ilmu-ilmu mendasar untuk menguasai dan menerapkan syariah Islam. Yang paling mendasar adalah kemampuan membaca Al-Quran.

UNESCO telah menetapkan bahwa buta aksara alphabet harus ditekan, dan setidaknya penduduk bumi harus mengenal huruf dan angka, mampu membaca dan berhitung, maka selayaknya ada kesepakatan di kalangan kaum muslimin bahwa definisi buta aksara bagi muslim adalah buta aksara AlQuran. Siapapun yang telah memeluk agama Islam, kemampuan basic yang harus dikuasainya adalah membaca huruf-huruf hijaiyyah, yang menjadi dasar penyusun Al-Quran.

\footnotetext{
${ }^{6}$ Azyumardi Azra (ed), Sejarah dan Ulum al-Qur'an (Cet. I; Jakarta: Pustaka Firdaus, 1999)
} 
Untuk itu Gerakan Pemberantasan Buta Al-Quran semestinya menjadi gerakan nasional. Jika sekarang beberapa SD menetapkan kemampuan baca huruf hijaiyyah sebagai persyaratan masuk, saya pikir bukan hal yang kontroversial, sebab bagi orangtua muslim adalah wajib bagi mereka membimbing anak-anaknya sejak masih kanak untuk membaca alif ba ta. Jika pada usia sangat dini sudah dituntunkan maka insya Allah tidak akan ada kesulitan membacanya di masa dewasanya. ${ }^{7}$

\section{Pemberantasan Buta Aksara dan Baca Al-Qur'an}

Melek aksara (juga disebut dengan melek huruf) adalah kemampuan membaca dan menulis.[1] Lawan kata "melek aksara" adalah buta huruf atau tuna aksara, di mana ketidakmampuan membaca dan menulis ini masih menjadi masalah, terutama di negara-negara Asia Selatan, Timur Tengah, dan Afrika (40\% sampai 50\%). Asia Timur dan Amerika Selatan memiliki tingkat buta huruf sekitar 10\% sampai 15\%. Biasanya, tingkat melek aksara dihitung dari persentase populasi dewasa yang mampu membaca dan menulis.

Melek aksara juga dapat diartikan sebagai kemampuan untuk menggunakan bahasa dan menggunakannya untuk mengerti sebuah bacaan, mendengarkan perkataan, mengungkapkannya dalam bentuk tulisan, dan berbicara. Dalam perkembangan modern kata ini lalu diartikan sebagai kemampuan untuk membaca dan menulis pada tingkat yang baik untuk berkomunikasi dengan orang lain, atau dalam taraf bahwa seseorang dapat menyampaikan idenya dalam masyarakat yang mampu baca-tulis, sehingga dapat menjadi bagian dari masyarakat tersebut.

Organisasi PBB untuk Pendidikan, Ilmu Pengetahuan dan Kebudayaan (UNESCO) memiliki definisi sebagai berikut:

“ Melek aksara adalah kemampuan untuk mengidentifikasi, mengerti, menerjemahkan, membuat, mengkomunikasikan dan mengolah isi dari

\footnotetext{
${ }^{7}$ Imam Jalaludin As Suyuthi, Samudera Ulumil Qur'an (Terjemah Kitab Al-itqan Fii Ulumil Qur'an) (PT.Bina ilmu, $\mathrm{tt}$ )
} 
rangkaian teks yang terdapat pada bahan-bahan cetak dan tulisan yang berkaitan dengan berbagai situasi.

Kemampuan baca-tulis dianggap penting karena melibatkan pembelajaran berkelanjutan oleh seseorang sehingga orang tersebut dapat mencapai tujuannya, di mana hal ini berkaitan langsung bagaimana seseorang mendapatkan pengetahuan, menggali potensinya, dan berpartisipasi penuh dalam masyarakat yang lebih luas.

Banyak analis kebijakan menganggap angka melek aksara adalah tolak ukur penting dalam mempertimbangkan kemampuan sumber daya manusia di suatu daerah. Hal ini didasarkan pada pemikiran yang berdalih bahwa melatih orang yang mampu baca-tulis jauh lebih murah daripada melatih orang yang buta aksara, dan umumnya orang-orang yang mampu baca-tulis memiliki status sosial ekonomi, kesehatan, dan prospek meraih peluang kerja yang lebih baik. Argumentasi para analis kebijakan ini juga menganggap kemampuan baca-tulis juga berarti peningkatan peluang kerja dan akses yang lebih luas pada pendidikan yang lebih tinggi.

Sebagai contoh di Kerala, India, tingkat kematian wanita dan anak-anak menurun drastis pada tahun 1960an, saat anak-anak gadis terdidik di saat reformasi pendidikan setelah tahun 1948 mulai berkeluarga. Walaupun begitu riset terbaru beragumentasi bahwa hasil yang didapat di atas mungkin lebih banyak disumbangkan sebagai hasil dari disekolahkannya anak-anak tersebut dibandingkan dari kemampuan baca-tulisnya saja. Walaupun begitu, di seluruh dunia fokus dari sistem pendidikan tetap merupakan konsep-konsep yang meliputi komunikasi melalui teks dan media cetak, dan hal ini masih merupakan dasar dari definisi melek aksara.

Dalam pandangan Islam, pendidikan wajib dilaksanakan sepanjang hayat, sehingga kehidupan bagi seorang muslim adalah proses dan sekaligus lingkungan pembelajaran. Jika seseorang berhenti belajar pasti tertinggal dan 
tergilas zaman. Selanjutnya, apabila kita memperhatikan ayat-ayat yang pertama diturunkan oleh Allah kepada Nabi Muhammad, maka nyatalah bahwa Allah telah menekankan perlunya orang belajar baca-tulis dan belajar ilmu pengetahuan.

Dalam hadis Rasulullah saw. Dikatakan:

Sebaik-baik kalian adalah siapa yang mempelajari Al-Qur'an dan mengajarkannya (HR. Al-Bukhari) "Siapa saja membaca satu huruf dari kitab Allah (Al-Qur'an), maka baginya satu kebaikan, dan satu kebaikan itu dibalas dengan sepuluh kali lipatnya (HR. At-Tirmidzi).

Dari hadis tersebut, jelaslah bahwa agama Islam mendorong umatnya agar menjadi umat yang pandai, dimulai dengan belajar baca tulis dan dilanjutkan dengan belajar berbagai macam ilmu pengetahuan. Sehingga islam menjadi agama yan kuat dan mudah diombang ambingkan dengan pihakpihak lain yang ingin menghancurkan islam

Al-Qur'an adalah kalamullah (firman Allah). Keutamaannya atas segala perkataan seperti keutamaan Allah 'Azza Wa Jalla atas seluruh makhluknya. Membacanya adalah amalan yang paling utama dilakukan oleh lisan dan bernilai ibadah. Bagaimana kita bisa paham terhadap isi Al-Qur'an dan mencintainya jika kita tidak bisa membacanya. ${ }^{8}$

Fenomena yang terjadi pada masyarakat, baik desa maupun di kota, banyak sekali orang tua yang buta aksara Al-Qur'an, jumlah buta aksara Alqu'an lebih banyak ibu-ibu atau kaum perempuan dibanding laki-laki. . Padahal posisi perempuan sebagai ibu di lingkungan rumah tangga dilihat dari segi tanggung jawab pemeliharaan dan pendidikan anak merupakan pusat pendidikan yang menentukan masa depan bangsa. Ibu adalah orang pertama yang memberikan sentuhan kasih sayang sedemikian rupa, mulai dari mengandung, melahirkan, menyusui dan memeliharanya dengan intensitas

\footnotetext{
${ }^{8}$ Khaeruddin, Metode Baca Tulis Al-Qur'an (Makassar: al-Ahkam, 2000)
} 
yang lebih sering dan kualitas interaksi yang bersifat edukatif. Atas dasar pertimbangan ini sangat tepat jika ibu disebut sebagai madrasah utama, sebagaimana diungkapkan Hafezd Ibrahim dalam sya'irnya:

Ibu adalah madrasah, apabila dipersiapkan dapat membentuk bangsa yang baik lagi kuat."Dengan demikian, posisi ibu jika dilihat dari segi tanggung jawab pemeliharaan dan pendidikan anak merupakan pusat pendidikan yang menentukan masa depan bangsa. Menurut Ali Syari'ati, konsep ibu dilambangkan dalam kata "Umm" seakar kata dengan "Imam" yang menggambarkan konsep kepemimpinan, dan kata "Ummah" yang menggambarkan kesatuan social manusia atau bangsa. Melalui pendekatan kebahasaan ini dapat ditarik pemahaman bahwa peranan ibu sebagai madrasah utama sangat strategis dalam membina dan menyiapkan komunitas baru (ummah) yang baik lagi kuat, serta meretas kader kepemimpinan (Imam) masa depan yang memiliki integritas watak dan pribadi yang bermoral, ketajaman intelektual dan kreativitas yang tinggi, serta memiliki jiwa leadership yang mantap dan penuh percaya diri.

Masalah ini memerlukan pemikiran yang mendalam guna dapat dicarikan jalan pemecahannya. Atas dasar masalah diatas maka pengelola Madrasah Al-fath mengadakan Program Pemberantasan Buta huruf Al-Qur'an untuk ibu-ibu, tapin tidak menutup kesempatan jika ada bapak-bapak yang berminat mengikutinya. Metode yang akan diterapkan dalam program pemberantasan buta aksara Al-Qur'an ini adalah metode Iqro.

\section{Penutup, Memperkenalkan Metode Iqro Kepada Peserta Didik}

Metode iqro adalah metode cepat belajar membaca Al-Qur'an yang dalam waktu relatif singkat dapat dengan mudah mengantarkan anak, remaja, dan orang dewasa bisa membaca Al-Qur'an. Metode Iqro terdiri atas enam jilid, disusun secara praktis dan sistematis. ${ }^{9}$

\footnotetext{
${ }^{9}$ KH. As'ad Humam, Balai Litbang LPTQ Nasional, Team Tadarus “AMM” Yogyakarta tahun 1980-an.
} 
Pemilihan metode iqro ini berdasarkan pada pengalaman di tingkat Diniyah Takmiliyah, peserta didik lebih cepat bisa membaca daripada metode klasikal, alasan lain karena Iqro memiliki beberapa sifat metode iqro, yaitu:

1. Metode as-salam metode awal dalam mempelajari Al-Quran. Dalam metode as-Salam terdapat delapan tahapan, yaitu :
a. Mengenal dan menghafal huruf hijaiyah berharokat fathah
b. Mengenal huruf hijaiyah berharokat fathah, kasroh dan dhammah
c. Pemanjangan dua huruf/ mad thobi'i
d. Mengenal huruf berharokat fathah tanwin
e. Bacaan sukun
f. Tanda baca tasydid
g. Latihan membaca Al-Qur'an

2. Metode Asy-Syafi'i ialah metode yang berisi pembelajaran mengenai pendalaman ilmu tajwid. Diantaranya ialah
a. Mengenal mad (mengenal alif kecil, ya kecil, dan wau kecil serta mengenal liin)

b. Cara membaca bacaan waqaf

c. Mengenal bacaan al (al-qamariyyah dan asy-syamsiyyah)

d. Huruf mad yang bertemu dengan hamzah washal

e. Mengenal lafadzh السّ

f. Mengenal mad dan tasydid

g. Bacaan huruf yang tidak berharakat di awal surat (mengenal tanda-tanda waqaf)

h. Pelajaran 1

$>$ Cara membaca Isti' adzah, basmalah dan awal surat

$>$ Cara menyambung dua surat

$>$ Cara menyambung yang salah

$>$ Kecepatan (ritme) bacaan 
i. Pelajaran II (Makharij Huruf)

$>$ Al-Jauf (Rongga Mulut dan Rongga Tenggorokan)

$>$ Al-Halaq (Tenggorokan)

$>$ Al-Lisan (Lidah)

$>$ Asy-Syafataan (Kedua Bibir)

$>$ Al-Khaisyum (Pangkal Hidung)

j. Pelajaran III (Sifat Huruf)

$>$ Sifat Huruf yang Mempumyai Lawan

Sifat Huruf Yang Tidak Mempunyai Lawan

k. Pelajaran IV Hukum Nun Sukun dan Tanwin

$>$ Idzhar Halqi

$>$ Idgham Bigunnah

$>$ Idgham Bilagunnah

$>$ Qalb/ Iqlab

$>$ Ikhfa Haqiqi

1. Pelajaran V (Hukum Mim Sukun )

$>$ Idzhar Syafawi

$>$ Ikhfa Syafawi

$>$ Idgham Mimi

m. Pelajaran VI (Hukum Idgham)

> Jenis-Jenis Idgham dari Sisi Makhraj dan Sifat

$\checkmark$ Idgham Mutamatsilain

$\checkmark$ Idgham Mutajanisain

$\checkmark$ Idgham Mutaqaribain

> Jenis-Jenis Idhgam dari Sisi Kesempurnaannya

$\checkmark$ Idgham Kamil

$\checkmark$ Idgham Naqish

n. Pelajaran VII (Hukum Mad)

> Mad Ashliy/Thabi'iy

$\checkmark$ Mad Ashliy/ Thabi'iy 
$>$ Mad Far'i

$\checkmark$ Bacaan Mad yang Bertemu dengan Hamzah

$\checkmark$ Bacaan Mad yang Bertemu dengan Sukun

o. Pelajaran VIII (Hukum Ra)

$>$ Tafkhim (Dibaca Tebal)

$>$ Tarqiq (Dibaca Tipis)

$>$ Tafkhim Tarqiq (Boleh Dibaca Tebal atau Tipis)

p. Kelas Pogram Pendalaman

Waqaf dan Ibtida'

$>$ Mengenal Nabr

$>$ Ayat-Ayat Gharibah

$>$ Mengenal Nun 'Iwadh atau Nun Washal

> Kaidah Membaca Mad Jaiz dari Jalur Thayyibatun Nasyr

$>$ Kaidah Seputar Bacaan Mad

Itulah semua pembelajaran yang terdapat dalam metode AsySyafi'i. Metode ini sudah pernah di praktekkan di Ma'had Imam Asy-Syafi'i Jakarta

3. Bacaan langsung tanpa dieja.

a. Privat/klasikal, penyimakan secara seorang demi seorang. Atau bila klasikal, santri dikelompokan berdasarkan persamaan kemampuan. Guru menerangkan pokok-pokok pelajaran secara klasikal dengan menggunakan peraga, dan secara acak santri dimohon membaca bahan latihan.

b. Asistensi, santri yang lebih tinggi jilidnya, dapat membantu menyimak santri lain.

c. Praktis, langsung menekankan praktek tanpa mengenalkan istilah-istilah ilmu tajwidnya, jadi langsung diajarkan bagaimana pengucapannya. 
d. Sistematis, disusun secara lengkap dan sempurna serta terencana, dengan komposisi huruf yang seimbang. Dimulai dari pelajaran yang amat dasar dan sederhana, sedikit demi sedikit, tahap demi tahap akhirnya ke tingkat suatu kalimat yang bermakna.

e. Variatif, disusun secara berjilid

f. Komunikatif, ungkapan kata rambu-rambu petunjuk akrab dengan pembaca sehingga menyenangkan bagi yang mempelajarinya. Begitupun lafal-lafalnya penuh dengan irama sehingga enak didengar dan dirasakan.

g. Fleksibel, bisa dipelajari oleh anak usia TK,SD, SLTP,SLTA, Mahasiswa bahkan orang-orang tua (manula) dan sebagainya. 


\section{Daftar Pustaka}

Manna' al-Qaththan, Mabahits fi 'Ulum al-Qur'an (Bairut: Dar al-Mansyurat alHadits, 1973)

M. Quraish Shihab, Membumikan Al-Qur'an; Fungsi dan Peran Wahyu dalam Kehidupan Masyarakat (Cet. XIX; Bandung: Mizan, 1999)

Repubik Indonesia, Undang-Undang Sisdiknas Tahun 2003 (Bandung: Fokus Media, 2003)

Rancangan Peraturan Daerah Kabupaten Sumenep Tentang Bebas Buta Aksara Al-qur'an Pada Satuan Pendidikan Dasar

Azyumardi Azra (ed), Sejarah dan Ulum al-Qur'an (Cet. I; Jakarta: Pustaka Firdaus, 1999)

Imam Jalaludin As Suyuthi, Samudera Ulumil Qur'an (Terjemah Kitab Al-itqan Fii Ulumil Qur'an) (PT.Bina ilmu, tt)

Khaeruddin, Metode Baca Tulis Al-Qur'an (Makassar: al-Ahkam, 2000) 